NASA Technical Memorandum 106699

\title{
Coordinated Fuel Cell System Programs for Government and Commercial Applications: Are We in a New Era?
}

Marvin Warshay and Paul Prokopius

Lewis Research Center

Cleveland, Ohio

Prepared for the

33rd Aerospace Sciences Meeting and Exhibit

sponsored by the American Institute of Aeronautics and Astronautics

Reno, Nevada, Januały 9-12, 1995

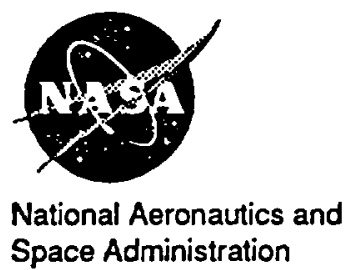




\title{
COORDINATED FUEL CELL SYSTEM PROGRAMS FOR GOVERNMENT AND COMMERCIAL APPLICATIONS: ARE WE IN A NEW ERA?
}

\author{
Marvin Warshay \\ and \\ Paul Prokopius \\ NASA Lewis Research Center \\ Cleveland, Ohio
}

\begin{abstract}
Though the fuel cell was invented in 1839 , it was not until the early 1960 's that the fuel cell power system was developed and used for a real application, for the NASA Space Mission Gemini. Unfortunately, fuel cell power systems did not, as a result, become in widespread use. Nevertheless, a great deal of progress has been made by both government and industry, culminating in many successful fuel cell power system demonstrations. Initially, each government agency and each private organization went its own way. Later, it became evident that coordination among programs was essential. An overview is presented of the current coordinated efforts by government and industry in fuel cells, with a sufficient historical background. The primary barriers to coordination of programs were institutional and differing application requirements. Initially, in the institutional area, it was the energy crisis and the formation of DOE which fostered close working relationships among government, manufacturers, and users. The authors discuss the fuel cell power system programs (of NASA, DOE, DOT, DOC, EPRI, GRI, industry, and universities), including missions and applications, technology advances, and demonstrations. The discussion covers the new Solar Regenerative Fuel Cell (RFC) program which has space, defense, and commercial terrestrial applications, and which is an excellent example of both program coordination and the Clinton Administration's dual-use application policy.
\end{abstract}

\section{Introduction}

Though the fuel cell was invented in 1839 (by Sir William Grove), it was not until over 100 years later that this new power device emerged from the laboratory and was used for a real application, namely for space power (for the NASA Gemini Mission of the 1960's). The fuel cell technology used for this historic space mission was of the type now commonly referred to as proton exchange membrane (PEM) and which was invented by W. T. Grubb in 1953 in the research laboratories of the General Electric Company (G.E.). (Another G.E. PEM research pioneer of the 1950's was L. W. Niedrach).

However, the early pioneer often credited with developing the first really practical fuel cell was $F$. T. Bacon who began his work in England in 1932. Before his alkaline electrolyte system was used by NASA in space (for the Apollo Moon Mission which followed Gemini), he demonstrated its capability by powering a welding machine, a circular saw, and a two-ton lift truck (all powered by Bacon's $5 \mathrm{~kW}$ fuel cell system). Thus, approximately a half century ago, the "table was set" not only for future space applications, but, even more so, for the much more extensive area of commercial applications.

\section{The Early Days}

In the early days, fuel cell programs, whether for government or commercial applications, developed along separate paths. NASA was carrying out under contract and in- 
house its space fuel cell programs. The DOD was carrying out its military fuel cell programs, principally for the U. S. Army applications. In the commercial arena, companies like Engelhard, Allis Chalmers, G.E., Pratt \& Whitney (P\&W), etc., had active programs aimed at commercial applications. Fuel cellpowered fork lift trucks and utility electric power and total energy generators were among the early commercial fuel cell systems being pursued.

However, while the same fuel cell company often performed in both the government and commercial fuel cell programs, there were no conscious efforts to effectively coordinate fuel cell programs. For example, P\&W of United Technologies Corporation (UTC) was developing both the Apollo Space Mission (as well as the Shuttle Space Mission Orbiter) fuel cell and the TARGET Program fuel cell for the gas utility industry as totally separate programs. In fact, the space fuel cell was alkaline (potassium hydroxide) while the commercial TARGET fuel cell was acidic (phosphoric acid). And this state of affairs held even with respect to fuel cell programs of two government agencies; the army and NASA did not really talk to each other about their respective fuel cell programs.

\section{The Start of Fuel Cell Program Coordination}

One could have made a very reasonable case for not coordinating the various fuel cell programs in the United States, especially for not coordinating government and commercial programs. For one thing, the application requirements tend to be different. For example, for NASA Space Missions low specific weight is a major requirement while low cost has a lower priority. (See figure 1 for an illustration of progress through the years in lowering space fuel cell specific weight). On the other hand, for commercial terrestrial applications, the reverse is true. And the unique ability of the fuel cell to supply potable water in space (the product of the electrochemical reaction) for crew consumption and for cabin humidification is of no value for commercial programs. Secondly, there is the traditional desire among U.S. private companies to keep government out of commercial programs because, in the view of U.S. industry, a government involvement would mean government meddling or, in the worst case, government control.

This latter reason could be classified as an institutional barrier to coordination of government agency and fuel cell programs and to industry and the government working together on both government and commercial fuel cell system programs. But Institutional barriers can be overcome more easily than can barriers resulting from programs having different mission or application requirements. Indeed, the long gasoline lines in the early 1970 's led to an almost overnight perception of an energy crisis in the U.S. and serious efforts by the utility industry to develop more efficient and environmentally acceptable sources of energy and energy conversion. Partially in response to this, UTC had organized fuel cell powerplant development programs with both the gas and electric utility industries, seemingly examples of unbeatable alliances of the manufacturer and two potential major industrial customers. However, the task turned out to be too much for either of these teams to handle. In particular, it would take more time and money to bring about commercial developments of fuel cells for stationary power applications. So, the Electric Utility Industry felt compelled to appeal to NASA to lead a national fuel cell program for stationary power which would include not only fuel cell manufacturers and utility industries, but also would include the government as a sponsor and technical participant. So the appeal of large sums of government money made available due to the "overnight crisis" also served to eliminate, also overnight, the institutional barrier preventing government and industry from working together in commercial fuel cell programs.

Ultimately, the government established ERDA (now the Department of Energy, DOE) to carry out its vast new program in energy. The new national commercial fuel cell program, led by ERDA received more than just the benefit of significant amounts of government dollars. It received a jump start by using the National Commercial Fuel Cell plan (that had 
been prepared by NASA) plus the technical management expertise of NASA-Lewis to plan and manage its PAFC first generation fuel cell program.

The result of the close coordination of government and industrial sponsorship and technical management (and with early inputs from the user community) was a more effective outcome than would have resulted had all the players proceeded on the "go-it-alone" style of the past. For the first generation PAFC program sponsored by DOE and the Gas Research Institute (GRE) (and technically managed by NASA), the program was brought to the threshold of commercialization by the late 1980's for both the multi-kilowatt on-site application and the multi-megawatt electric utility applications.

Spearheaded by the DOE and the Electric Power Research Institute (EPRI), the National Fuel Cell Coordinating Group (NFCCG) was established in 1976 to coordinate the U.S. efforts in fuel cells. Founding member organizations were DOE, EPRI, NASA, and DOD. As other government and not for profit organizations developed active fuel cell programs they joined the NFCCG to more effectively coordinate their programs. In the former category were organizations like TVA and EPA; in the latter category is GRI. Today, Japanese and European organizations support the NFCCG in sponsoring the Fuel Cell Seminar. Like fuel cell programs, coordination has gone international.

\section{$\underline{\text { Status of Current Programs }}$}

\section{Stationary Applications}

The major areas of fuel cell system applications are stationary power, transportation, defense, and aerospace. The largest effort in the U.S., which has been the case for over two decades, continues to be for stationary power applications. The lead organization is the DOE. Figure 2, which was taken from a DOE presentation, illustrates the complex nature of the program coordination in this application area. The program goal of DOE for this application area is to "Develop cost effective, efficient, and environmentally benign fuel cell systems which operate on natural gas and coal-based fuels." Obviously, the GRI program shares this DOE goal with respect to use of natural gas, which tended to be fuel cell powerplant systems in the multikilowatt class for on-site applications. The EPRI program emphasis has been on the multimegawatt class of fuel cell powerplants suitable for electric utility power generation.

As the result of coordinated DOE and GRI programs, $200 \mathrm{~kW}$, natural gas-fueled, on-site, PAFC powerplants have entered the "early entry," commercial marketplace worldwide. For some purchasers, like the DOD which has bought twelve for the three services, these $200 \mathrm{~kW}$ PAFC powerplants will represent demonstration units. These are being manufactured by International Fuel Cells (IFC), a division of UTC. IFC was formed as a joint venture with Toshiba of Japan for commercial PAFC programs. IFC has also manufactured multi-megawatt-sized (from 1 MW to $11 \mathrm{MW}$ ) PAFC powerplants which are being demonstrated in Italy and Japan. EPRI is monitoring PAFC powerplant demonstrations underway worldwide.

For the first generation, low temperature (around $200^{\circ} \mathrm{C}$ ) PAFC system the GRI has taken over the lead role as DOE has shifted to a greater program emphasis on the second generation molten carbonate fuel cell system (MCFC), which operated at around $650^{\circ} \mathrm{C}$, and the third generation solid oxide fuel cell (SOFC) system, which operates at around $1000^{\circ} \mathrm{C}$ with a zirconia electrolyte. Two thirds of the DOE fuel cell \$51+ Million annual budget for stationary power has been directed toward the MCFC systems. The MCFC system has matured to the point of full size stack field demonstrations of powerplants (built in 1994) to be started in 1995. Two are scheduled. One has been built by the Energy Research Corporation (ERC), the other by M-C Power. A major participant in this phase of the coordinated program is the industrial/user sector, which is providing a $60 \%$ cost-share for these demonstrations.

Greater fuel flexibility for the MCFC and SOFC systems than for the PAFC system is an attractive characteristic. For example, $\mathrm{CH} 4$ and $\mathrm{CO}$ can be handled more directly by 
the MCFC (via internal reforming if desired, which is not an option for the PAFC). However, the MCFC sulfur tolerance is still $<1 \mathrm{ppm}$, as is the case for the SOFC system. In this connection, two DOD programs are underway to enable both the MCFC and the SOFC systems to use, via advanced fuel processing, very high sulfur military logistics fuels such as JP-8 and DF-2.

The Westinghouse tubular SOFC concept continues to get the bulk of the SOFC dollars. However, planar SOFC concepts are getting increased attention with funding from NASA, DOD, and EPRI, in addition to that of DOE. An important test for 1995 is the test of an advanced tubular $100 \mathrm{~kW}$ SOFC generator at a gas utility user site.

\section{Transportation Applications}

It was only in the late 1980's that fuel cells for transportation applications began to come into their own. Today, it is a growing field with the Department of Energy, the lead government agency. The PEM system has experienced a resurgence of interest, principally because of the transportation applications. However, despite significant PEM technology advances, in membrane and in electrode catalyst loading, it took state legislation (that required zero pollution passenger cars) to bring the U.S. big three automobile manufacturers very actively into the fuel cell program. Initially, GM formed a team consisting of themselves, Ballard Power Corporation, los Alamos National Laboratory, and Dow Chemical. The first phase of this DOE/industry PEM fuel cell program is complete. DOE has recently added Phase II efforts with Ford and with Chrysler in parallel with GM Phase II effort.

In September of 1993, the Clinton Administration began a joịt government/industry effort to produce a cleaner, more efficient, cost effective passenger car. The government agency effort, call the Partnership for a New Generation of Vehicles (PNGV), is being led by the U.S. Department of Commerce. There is a great interest in the development of the fuel cell for this program. In addition to the passenger car, an active fuel cell bus program is well underway.
In the U.S., Georgetown University successfully carried out a program to develop a 30 foot PAFC bus suitable for college campus transportation. Fuji of Japan and H-Power of the U.S. worked on the PAFC powerplant part of the bus, with Fuji supplying the fuel cell stacks based on technology that they had licensed from Engelhard. Georgetown has continued in this area by starting a program to develop a 40 foot fuel cell advanced commercial bus. Funding has come from DOT, DOE, DOD, and the South Coast Air Quality Management District. In a separate program, Ballard of Canada is developing a PEM fuel cell bus. Finally, in the study and planning stage is a joint effort sponsored by the South Coast Air Quality Management District (of CA) and DOE to develop fuel cells for heavy duty transportation applications, namely for locomotives.

\section{Defense Applications}

The DOD interest in fuel cell power systems is as a user of base power or for defense missions on land, in the sea, or in the air. Previously, the nature of the DOD interest in base power had been mentioned. With PAFC powerplants, the DOD role is one of evaluation of $200 \mathrm{~kW}$ powerplants at various sites. On the other hand, with the high temperature MCFC and SOFC powerplant systems of the Advanced Research Projects Agency (ARPA) of DOD is investing over $\$ 20 \mathrm{M}$ to develop advanced systems capable of handling very high sulfur JP-8 and DF-2 fuels for transportable and fixed base applications. The Logistics Fuels Program, initiated in December 1993, will result in $30 \mathrm{kw}$ demonstrations of the Westinghouse tubular SOFC and ERC's MCFC operating on both JP-8 and DF-2. Haldor-Topsoe is the subcontractor for fuel processing, with the Jet Propulsion Lab supplying significant technical fuel processing support to the NASA management of the project. The Mobile Electric Power Program, just getting underway, will incorporate planar SOFC technologies (Ceramatec and Technology management, Inc.) and advanced fuel processing schemes. Low power, high energy density person portable fuel cell systems will 
also be developed under this program.

ARPA is supporting a program in Fuel Cell Direct Oxidation of Methanol. Success of this project would simplify the fuel cell system by eliminating the need for a fuel processing subsystem. This would produce a more compact and less costly fuel cell system. potential applications would be both in stationary power and in transportation. For the passenger car, a liquid fuel like methanol would be much more acceptable than hydrogen gas as the fuel (for which there also would be no need for a fuel processor subsystem). Historically, the performance and life of a direct oxidation fuel cell were not attractive. In the ARPA program, improvements in direct oxidation fuel cell performance has been reported. Also, some promising new PEM fuel cell membranes have been developed which have reduced, significantly, the loss of methanol via membrane diffusion, a common characteristic of PEM nafion membranes. An ARPA program is nearing completion to develop fuel cell powerplant systems that will increase SOA energy density by three times for Unmanned Undersea Vehicles. The SOA system uses AgZn primary batteries. Both a PEM fuel cell system and an Aluminum Oxygen semi-cell system were developed for the application. The AluminumOxygen system (of Loral Defense Systems) turned out to be more appropriate for the application than did the IFC PEM fuel cell system.

In the large government Defense Conversion Program fuel cells were not among the strongly supported technologies. Only in the ARPA-funded TRP (technology reinvestment) small business innovative research (SBIR) part of the program is fuel cell research being carried out.

\section{Aerospace Applications}

The main focus of NASA's fuel cell program has been on the Solar Regenerative Fuel Cell (RFC) power concept. The principal NASA missions for which the RFC power system is being developed are International Space Station and the future Lunar/Mars missions. In the former case it is being considered as a replacement for the nickel hydrogen batteries in the future, when the batteries have to be replaced in space. In the latter case, the solar RFC is considered enabling technology for providing Lunar and Mars surface power. For both missions, the PEM technology (for both the electrolyzer and fuel cell subsystems) best meets the requirements.

NASA and the DOD are also cooperating on developing fuel cell power systems to potentially satisfy the requirements of missions involving unmanned high altitude aircraft.

As an outgrowth of its Solar RFC project, NASA Lewis Research Center (LerC) has initiated a program to develop a renewable energy system testbed to evaluate, characterize, and demonstrate fully integrated Solar RFC systems, as well as their major subsystems, for space, military, and commercial applications. A multi-agency management team, led by NASA LeRC, is implementing the program through a unique international coalition which encompasses government, industry, and university participants. Construction of the LeRC $25 \mathrm{~kW}$ RFC system testbed at the NASA-Jet Propulsion Laboratory facility at Edwards Air Force Base has been completed. Planning for the first commercial RFC system demonstration is underway. The RFC program constitutes an excellent example of both program coordination and the Clinton Administration's dual-use application policy.

\section{Conclusion}

Coordination among government and industry fuel cell programs is a reality today because it was a necessity for all parties. The traditional barriers that resulted in each government agency and each private organization going its own way in fuel cell system development have been overcome in the United States. In fact, the various fuel cell program organizations are actively working to effectively coordinate the programs. The formation of the NFCCG in the late 1970's and the establishment of the Clinton Administration's dual-use application policy have aided this national effort significantly. 


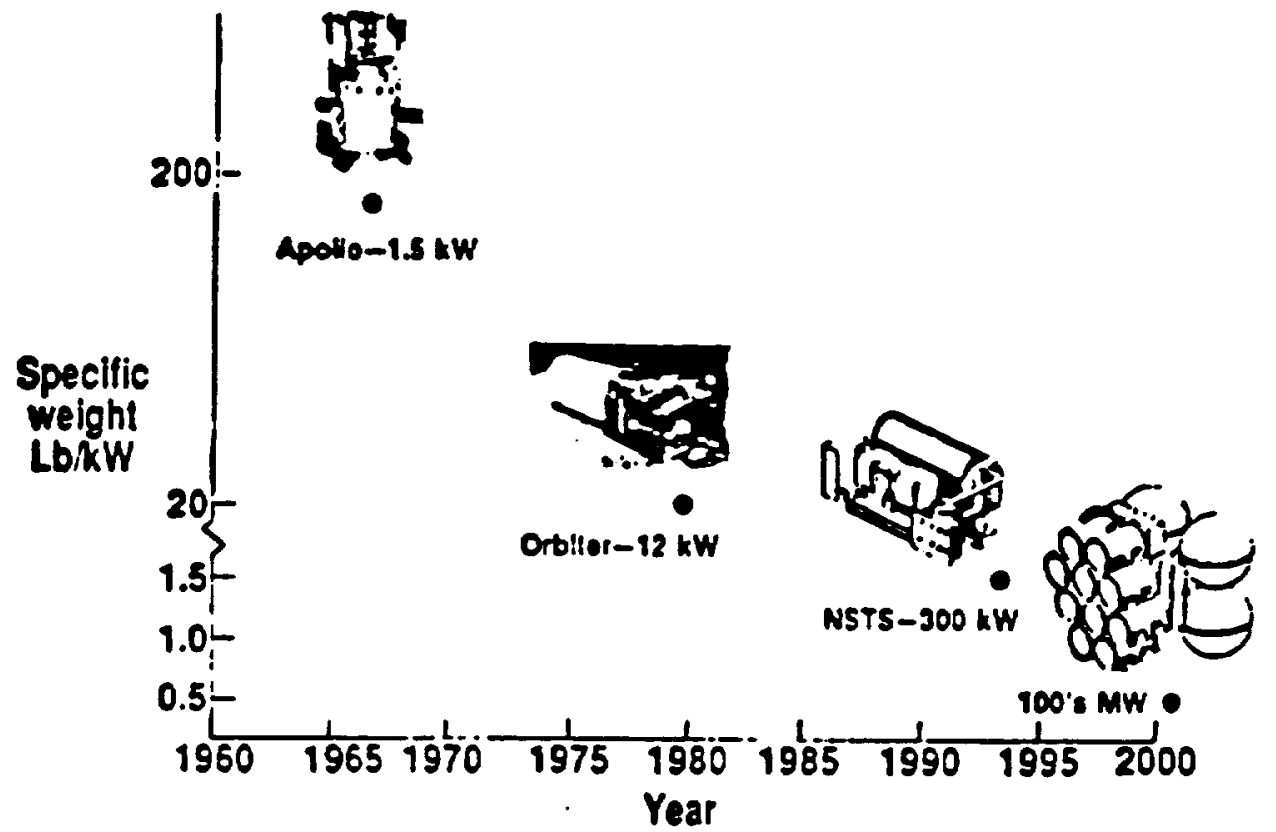

Fig. 1. Progress in Fuel Cell Space Power

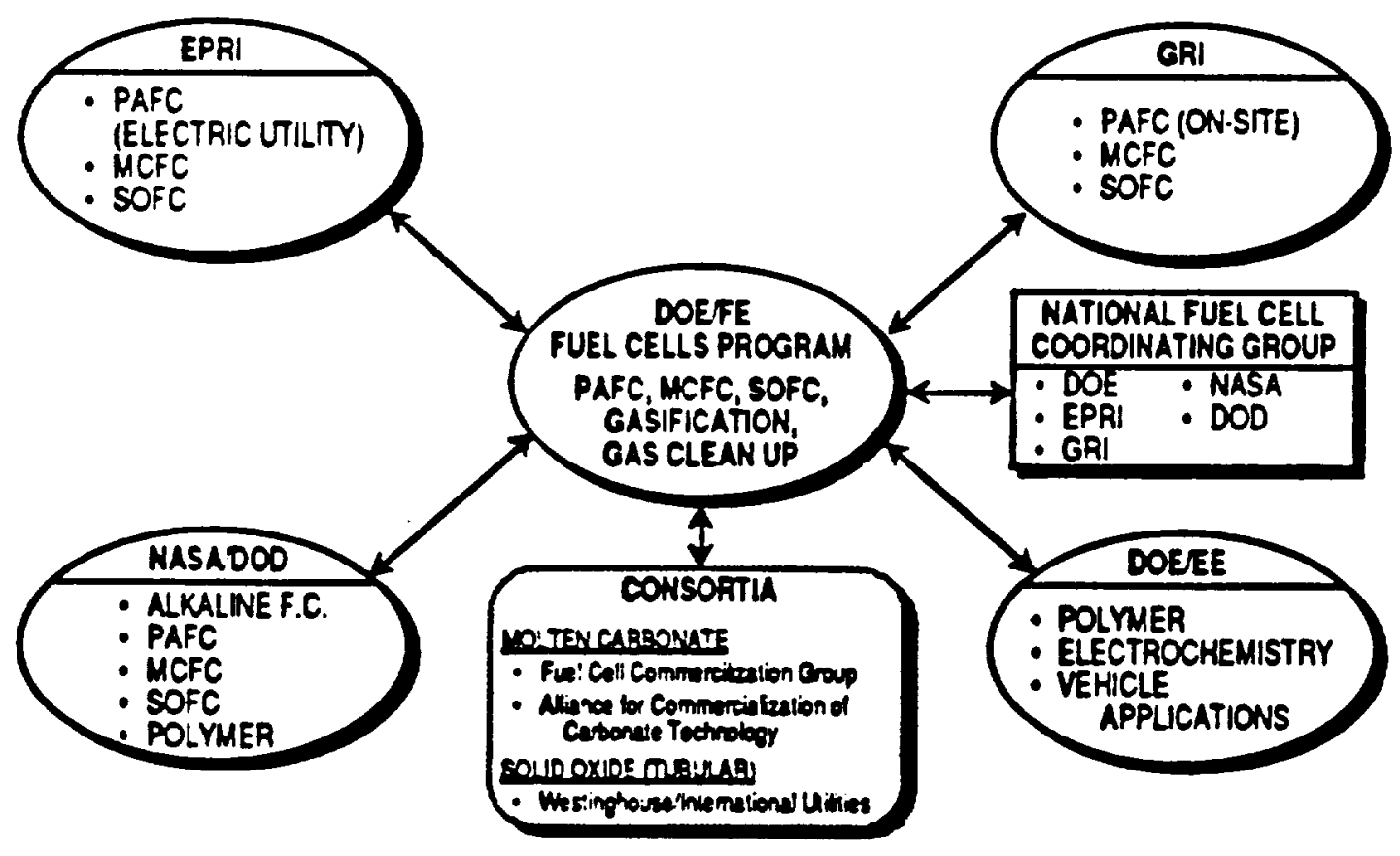

Fig. 2. DOE Fuel Cell Program Interactions 



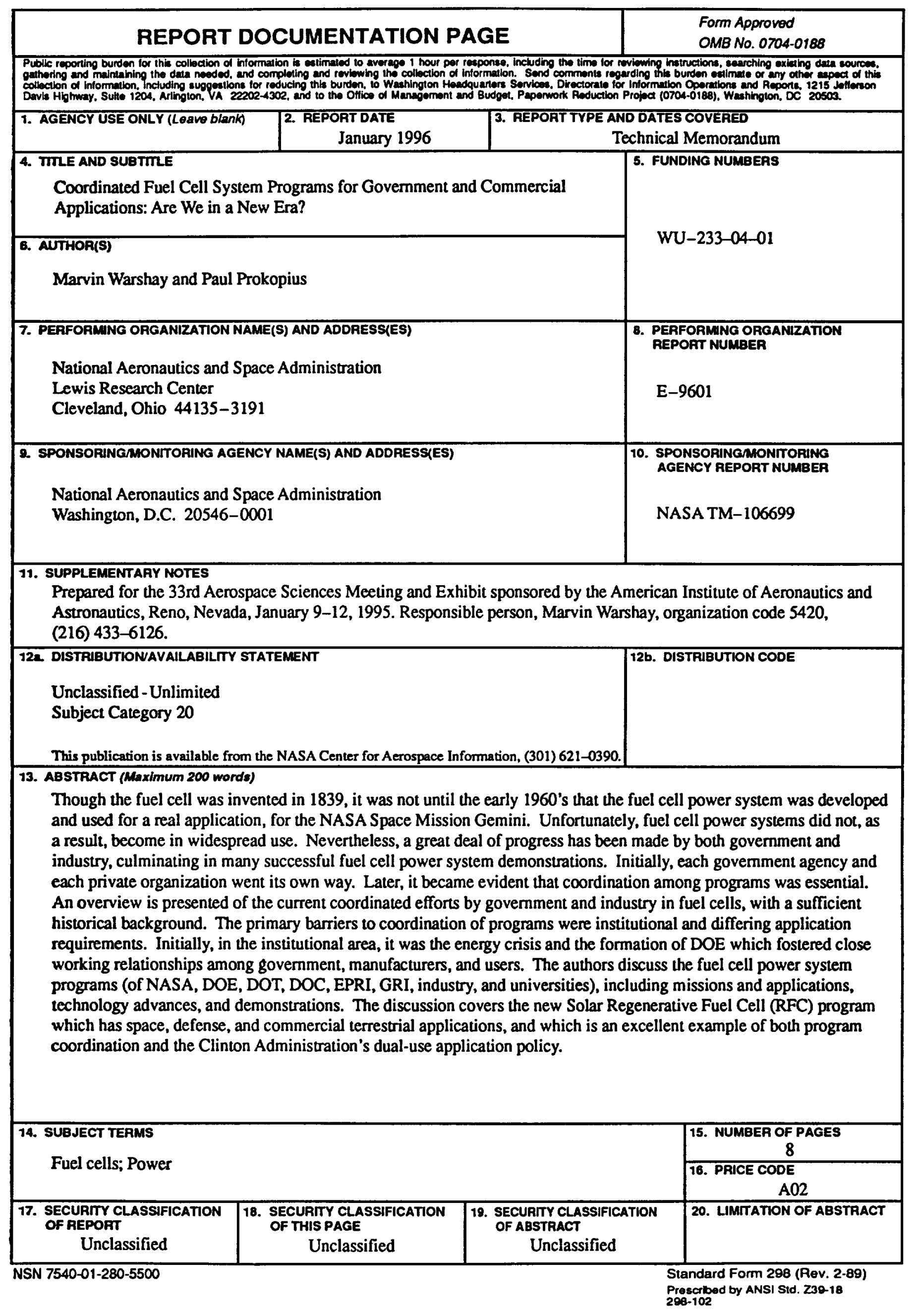


National Aeronautlcs and

Space Administration

Lewis Research Center

21000 Brookpark Rd.

Cleveland, $\mathrm{OH}$ 44135-3191

Omlalal Bualneas

Penally for Pivato Use $\$ 300$

POSTMASTER: II Undellverable - Do Not Return 